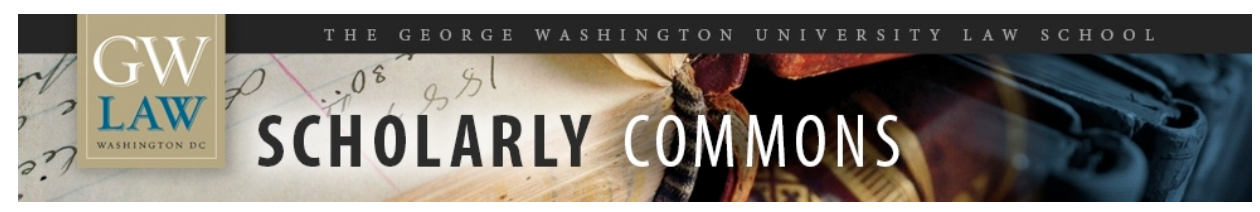

GW Law Faculty Publications \& Other Works

Faculty Scholarship

2007

\title{
Law and Society Approaches to Cyberspace
}

Paul Schiff Berman

George Washington University Law School, pberman@law.gwu.edu

Follow this and additional works at: https://scholarship.law.gwu.edu/faculty_publications

Part of the Law Commons

\section{Recommended Citation}

Law and Society Approaches to Cyberspace, Ashgate Publishing, 2007.

This Book Part is brought to you for free and open access by the Faculty Scholarship at Scholarly Commons. It has been accepted for inclusion in GW Law Faculty Publications \& Other Works by an authorized administrator of Scholarly Commons. For more information, please contact spagel@law.gwu.edu. 
Law and Society Approaches to Cyberspace 


\section{The International Library of Essays in Law and Society \\ Series Editor: Austin Sarat}

Titles in the Series:

Law and Religion

Gad Barzilai

Police and Policing Law

Jeannine Bell

Law and Society Approaches to Cyberspace

Paul Schiff Berman

Law and Families

Susan B. Boyd and Helen Rhoades

Rhetoric of Law

Marianne Constable and Felipe Gutterriez

Law in Social Theory

Roger Cotterrell

Ethnography and Law

Eve Darian-Smith

International Law and Society

Laura Dickinson

Legal Lives of Private Organizations

Lauren Edelman and Mark C. Suchman

Courts and Judges

Lee Epstein

Consciousness and Ideology

Patricia Ewick

Prosecutors and Prosecution

Lisa Frohmann

Intellectual Property

William T. Gallagher

Human Rights, Law and Society

Lisa Hajjar

Race, Law and Society

Ian Haney López

The Jury System

Valerie P. Hans

Crime and Criminal Justice

William T. Lyons, Jr.

Regulation and Regulatory Processes

Robert Kagan and Cary Coglianese

\section{Law and Social Movements}

Michael McCann

Colonial and Post-Colonial Law

Sally Merry

Social Science in Law

Elizabeth Mertz

Sexuality and Identity

Leslie J. Moran

Law and Poverty

Frank Munger

Rights

Laura Beth Nielsen

Governing Risks

Pat O'Malley

Lawyers and the Legal Profession, Volumes I and II

Tanina Rostain

Capital Punishment, Volumes I and II

Austin Sarat

Legality and Democracy

Stuart A. Scheingold

The Law and Society Canon

Carroll Seron

Popular Culture and Law

Richard K. Sherwin

Law and Science

Susan Silbey

Immigration

Susan Sterett

Gender and Feminist Theory in Law and Society

Madhavi Sunder

Procedural Justice, Volumes I and II

Tom R. Tyler

Trials

Martha Merrill Umphrey 


\section{Law and Society Approaches to Cyberspace}

Edited by

Paul Schiff Berman

University of Connecticut, USA

ASHGATE 
(C) Paul Schiff Berman 2007. For copyright of individual articles please refer to the Acknowledgements.

All rights reserved. No part of this publication may be reproduced, stored in a retrieval system or transmitted in any form or by any means, electronic, mechanical, photocopying, recording or otherwise without the prior permission of the publisher.

Wherever possible, these reprints are made from a copy of the original printing, but these can themselves be of very variable quality. Whilst the publisher has made every effort to ensure the quality of the reprint, some variability may inevitably remain.

Published by

Ashgate Publishing Limited

Gower House

Croft Road

Aldershot

Hampshire GU11 3HR

England

Ashgate Publishing Company

Suite 420

101 Cherry Street

Burlington, VT 05401-4405

USA

Ashgate website: http://www.ashgate.com

\section{British Library Cataloguing in Publication Data}

Law and society approaches to cyberspace. - (The

international library of essays in law and society)

1. Computer networks - law and legislation 2. Internet -

Law and legislation 3. Sociological jurisprudence

I. Berman, Paul Schiff

343'.09944

\section{Library of Congress Cataloging-in-Publication Data}

Law and society approaches to cyberspace / edited by Paul Schiff Berman.

p. cm. - (International library of essays in law and society)

Includes index.

1. Internet - Law and legislation - United States. 2. Computer networks - Law and

legislation - United States. 3. Internet - Government policy-United States. 4.

Computer networks-Social aspects-United States. 5. Internet-Social aspects-United

States. I. Berman, Paul Schiff.

KF390.5.C6L385 2007

343.7309'944-dc22

ISBN: 978-0-7546-2493-6

Printed in Great Britain by TJ International Ltd, Padstow, Cornwall 


\section{Contents}

Acknowledgements

vii

Series Preface

ix

Introduction

$\mathrm{xi}$

\section{PART I CYBERSPACE AND INTELLECTUAL PARADIGMS}

1 Sherry Turkle (2004), 'How Computers Change the Way We Think', Chronicle of Higher Education, 26, pp. 1-5.

2 Richard J. Ross (2002), 'Communications Revolutions and Legal Culture: An Elusive Relationship', Law and Social Inquiry, 27, pp. 637-84.

\section{PART II CYBERSPACE AND METAPHOR}

3 Dan Hunter (2003), 'Cyberspace as Place and the Tragedy of the Digital Anticommons', California Law Review, 91, pp. 439-519.

\section{PART III CYBERSPACE AND GLOBALIZATION}

4 Gunther Teubner (2004), 'Societal Constitutionalism: Alternatives to State-Centred Constitutional Theory?', in Christian Joerges, Inger-Johanne Sand and Gunther Teubner (eds), International Studies in the Theory of Private Law Transnational Governance and Constitutionalism, Oxford: Hart Publishing, pp. 3-28.

5 Paul Schiff Berman (2005), 'Towards a Cosmopolitan Vision of Conflict of Laws: Redefining Governmental Interests in a Global Era', University of Pennsylvania Law Review, 153, pp. 1819-82.

\section{PART IV CYBERSPACE AND LEGAL REALISM}

6 James Boyle (1997), 'Foucault in Cyberspace: Surveillance, Sovereignty, and Hardwired Censors', University of Cincinnati Law Review, 66, pp. 177-205.

7 Margaret Jane Radin (2004), 'Regulation by Contract, Regulation by Machine', Journal of Institutional and Theoretical Economics, 160, pp. 142-56. 


\section{PART V CYBERSPACE AND FREEDOM OF EXPRESSION}

8 Lawrence Lessig (1998), 'What Things Regulate Speech: CDA 2.0 vs. Filtering', Jurimetrics Journal, 38, pp. 629-70.

9 Jack M. Balkin (2004), 'Digital Speech and Democratic Culture: A Theory of Freedom of Expression for the Information Society', New York University Law Review, 79, pp. 1-58.

\section{PART VI CYBERSPACE AND COPYRIGHT}

10 Jane C. Ginsburg (2001), 'Copyright and Control Over New Technologies of Dissemination', Columbia Law Review, 101, pp. 1613-47.

11 Jessica Litman (2004), 'Sharing and Stealing', Hastings Communications and Entertainment Law Journal, 27, pp. 1-50.

\section{PART VII CYBERSPACE AND PRIVACY}

12 Julie E. Cohen (2000), 'Examined Lives: Informational Privacy and the Subject as Object', Stanford Law Review, 52, pp. 1373-438.

\section{PART VIII CYBERSPACE, IDENTITY AND COMMUNITY I}

13 Anupam Chander (2002), 'Whose Republic?', University of Chicago Law Review, 65, pp. 1479-500.

14 Jerry Kang (2000), 'Cyber-Race', Harvard Law Review, 113, pp. 1130-208.

\section{PART IX CYBERSPACE, IDENTITY AND COMMUNITY II}

15 Jennifer L. Mnookin (1996), 'Virtual(ly) Law: The Emergence of Law in LambdaMOO', Journal of Computer-Mediated Communication, 2, pp. 645-701.

16 James Grimmelmann (2004), 'Virtual Worlds as Comparative Law', New York Law School Law Review, 1, pp. 147-84. 


\section{Acknowledgements}

The editor and publishers wish to thank the following for permission to use copyright material.

American Bar Assocaition for the essay: Lawrence Lessig (1998), 'What Things Regulate Speech: CDA 2.0 vs. Filtering', Jurimetrics Journal, 38, pp. 629-70. Copyright (C) 1998 American Bar Association.

Jack M. Balkin (2004), 'Digital Speech and Democratic Culture: A Theory of Freedom of Expression for the Information Society', New York University Law Review, 79, pp. 1-58. Copyright (C) 2004 Jack M. Balkin.

Blackwell Publishing for the essay: Richard J. Ross (2002), 'Communications Revolutions and Legal Culture: An Elusive Relationship', Law and Social Inquiry, 27, pp. 637-84. Copyright (C) 2002 American Bar Foundation.

James Boyle for the essay: James Boyle (1997), 'Foucault in Cyberspace: Surveillance, Sovereignty, and Hardwired Censors', University of Cincinnati Law Review, 66, pp. 177-205. Copyright (C1997 James Boyle, Professor of Law.

Chicago-Kent College of Law for the essay: James Grimmelmann (2004), 'Virtual Worlds as Comparative Law', New York Law School Law Review, 1, pp. 147-84: This article is available under the Creative Commons Attribution 2.5 license (http://creativecommons.org/licenses/ by/2.5/).

Columbia Law Review for the essay: Jane C. Ginsburg (2001), 'Copyright and Control Over New Technologies of Dissemination', Columbia Law Review, 101, pp.1613-47.

Copyright Clearance Center for the essays: Julie E. Cohen (2000), 'Examined Lives: Informational Privacy and the Subject as Object', Stanford Law Review, 52, pp. 1373-1438. Copyright (C) 2000 Julie E. Cohen and the Board of Trustees of the Leland Stanford Junior University; Anupam Chander (2002), 'Whose Republic?', University of Chicago Law Review, 65, pp. 1479-500. Copyright (C) 2002 University of Chicago Law Review.

Hart Publishing Limited for the essay: Gunther Teubner (2004), 'Societal Constitutionalism: Alternatives to State-Centred Constitutional Theory?', in Christian Joerges, Inger-Johanne Sand and Gunther Teubner (eds), International Studies in the Theory of Private Law Transnational Governance and Constitutionalism, Oxford: Hart Publishing, pp. 3-28.

Harvard Law Review for the essay: Jerry Kang (2000), 'Cyber-Race', Harvard Law Review, 113, pp. 1130-208. Copyright (C) 2000 Harvard Law Review. 
Journal of Computer-Mediated Communication for the essay: Jennifer L. Mnookin (1996), 'Virtual(ly) Law: The Emergence of Law in LambdaMOO', Journal of Computer-Mediated Communication, 2, pp. 645-701.

O’Brien Center for Scholarly Publications for the essay: Jessica Litman (2004), 'Sharing and Stealing', Hastings Communications and Entertainment Law Journal, 27, pp. 1-50. Copyright (C) 2004 by University of California, Hastings College of the Law.

Margaret Jane Radin (2004), 'Regulation by Contract, Regulation by Machine', Journal of Institutional and Theoretical Economics, 160, pp. 142-56. Copyright (C) 2004 Margaret Jane Radin.

Sherry Turkle for the essay: Sherry Turkle (2004), 'How Computers Change the Way We Think', Chronicle Higher Education, 26, pp 1-5. Copyright (C) 2004 Sherry Turkle.

University of California for the essay: Dan Hunter (2003), 'Cyberspace as Place and the Tragedy of the Digital Anticommons', California Law Review, 91, pp. 439-519. Copyright (C 2003 California Law Review, Inc.

University of Pennsylvania Law School for the essay: Paul Schiff Berman (2005), 'Towards a Cosmopolitan Vision of Conflict of Laws: Redefining Governmental Interests in a Global Era', University of Pennsylvania Law Review, 153, pp. 1819-82.', University of Pennsylvania Law Review, 153, pp. 1819-82.

Every effort has been made to trace all the copyright holders, but if any have been inadvertently overlooked the publishers will be pleased to make the necessary arrangement at the first opportunity. 


\section{Series Preface}

The International Library of Essays in Law and Society is designed to provide a broad overview of this important field of interdisciplinary inquiry. Titles in the series will provide access to the best existing scholarship on a wide variety of subjects integral to the understanding of how legal institutions work in and through social arrangements. They collect and synthesize research published in the leading journals of the law and society field. Taken together, these volumes show the richness and complexity of inquiry into law's social life.

Each volume is edited by a recognized expert who has selected a range of scholarship designed to illustrate the most important questions, theoretical approaches, and methods in her/his area of expertise. Each has written an introductory essay which both outlines those questions, approaches, and methods and provides a distinctive analysis of the scholarship presented in the book. Each was asked to identify approximately 20 pieces of work for inclusion in their volume. This has necessitated hard choices since law and society inquiry is vibrant and flourishing.

The International Library of Essays in Law and Society brings together scholars representing different disciplinary traditions and working in different cultural contexts. Since law and society is itself an international field of inquiry it is appropriate that the editors of the volumes in this series come from many different nations and academic contexts. The work of the editors both charts a tradition and opens up new questions. It is my hope that this work will provide a valuable resource for longtime practitioners of law and society scholarship and newcomers to the field.

AUSTIN SARAT

William Nelson Cromwell Professor of Jurisprudence and Political Science Amherst College 



\section{Introduction}

The very title of this volume, Law and Society Approaches to Cyberspace, contains within it two significant puzzles that demand exploration at the outset. First, what constitutes a 'law and society approach' to any particular subject? And second, why refer to online interaction as 'cyberspace' and in what way is cyberspace a distinctive topic for legal analysis? Thinking in more detail about both of these puzzles will help to elucidate the themes contained in the provocative essays that follow.

\section{A Law and Society Approach}

It may seem odd to be asking, in 2007, what a law and society approach actually is. After all, the law and society movement has been around for at least forty years now, and the movement's legal realist forebears achieved prominence as far back as the beginning of the last century. So, one might think that by this time we should all agree on the methodological paradigms law and society (or sociolegal) scholars use. Yet, for better or worse, the law and society movement has long had an extraordinarily 'big tent' approach to the issue of methodology.

As a result, a law and society approach can plausibly be said to describe a diverse series of encounters with law. We must therefore begin as Rick Abel once did: 'When asked what I study, I usually respond gnomically: everything about law except the rules' (Abel, 1995). Abel's comment reflects the idea that, while lawyers usually treat rules as a given and therefore focus on ways to understand, manipulate and systematize those rules, sociolegal scholars study the world in which the rules are created and the world in which the rules are applied. Accordingly, a law and society approach considers the institutional structures, behaviours, personnel, culture and meaning that form the social context, symbolic content and practical application of those rules in everyday life. This is the source of the classic law and society distinction between law as it exists 'on the books' and law 'in action' (Pound, 1910).

But how should law 'in action' be studied? Here is where the methodological polymorphousness emerges, and it is largely attributable to the diversity of theoretical approaches from which the law and society movement emerged. For example, some sociolegal scholarship can trace its origins to nineteenth-century (and earlier) historians, who sought to put law in broader contexts and chart changes over time (for example, Maine, 1861; Montesquieu, 1756; Parsons, 1966; Redfield, 1964; Savigny, 1831; Tönnies, 1963). Others hearken back to the classic social theory of Marx, Weber and Durkheim, each of whom studied law as part of the transformation of social, political and economic institutions that took place during the passage from traditional to industrial society (for example, Durkheim, 1964, 1973; Hirst, 1972; Hunt, 1978; Weber, 1978). Meanwhile, anthropological studies of law outside of courts or other formal institutions led to both a broader understanding of what counts as law and a focus on 'dispute resolution' as an essential lens for viewing forces of social control, hierarchy and resistance (for example, Bohannan, 1967; Collier, 1975; Hoebel and 
Llewellyn, 1941; Moore, 1969; Nader, 1965). Political scientists, following a 'behaviourist' approach, turned the focus away from abstract appellate opinions to the front-line day-to-day operations of court bureaucracies (for example, Blumberg, 1967; Feeley, 1977; Packer, 1968). Psychologists began studying such issues as law and popular opinion, and the construction of deviance (for example, Cohen, Robson and Bates, 1958; Kalven and Zeisel, 1966; Moore, and Callahan, 1944; Rose and Press, 1955). And of course the legal realist influence led to an emphasis on empirical understanding of judicial decision-making, power dynamics and the relationship of legal institutions and societal processes (for example, Peltason, 1955; Schmidhauser, 1960; Schubert, 1965).

And all of that is only law and society as it was in the early days! In the late 1970s and 1980s, sociolegal and critical scholars began to incorporate the insights of postmodern theory, tracing the political and ideological components inherently imbedded in law and legal reasoning (for example, Frug, G.E. 1984; Frug, M.J. 1985; Gordon, 1984; Kairys, 1982; Kelman, 1987; Kennedy, 1976; Unger, 1983). Subsequently, law and society scholarship took a more interpretive turn, building on the work of Gramsci (1971), Foucault (1980), de Certeau (1984) and the vast, vaguely defined field of cultural studies. Thus, sociolegal scholars began to engage in cultural analyses of law, taking a constitutive, rather than an instrumental, approach to legal rules, and focusing not on how law might serve progressive goals, but instead on how law works within a society to help shape social relations (for example, Hunt, 1978; Silbey, 1992). This constitutive approach viewed legal discourse, categories and procedures as a framework through which individuals in society come to apprehend reality. Thus, law was seen not merely as a coercive force operating externally to affect behaviour and social relations, but also as a lens through which we view the world and actually conduct social interaction. The constitutive turn, when combined with the earlier social science emphasis on law's hegemonic power, became a study of legal consciousness itself: the ways in which 'legality is experienced and understood by ordinary people as they engage, avoid, or resist the law and legal meanings' (Ewick and Silbey, 1998, p. 35). Thus, scholars have attempted to study law in 'everyday life', asking how 'commonplace transactions and relationships come to assume or not assume a legal character? And in what ways is legality constituted by these popular understandings, interpretations, and enactments of law?' (Ewick and Silbey, 1998, p. 33). By emphasizing the everyday moments when people negotiate their own understanding of legality, such scholarship sought to walk the fine line between liberal theory's assumption of autonomous individuals exerting free will in society, and structuralism's conception of the individual as determined by social and economic forces (Mezey, 2001). Thus, this approach operated as a critique not only of liberal conceptions of law (which tend to view law as a self-contained system of rules), but also of many Marxist critiques (which tend to view law as unidirectional, emanating from capitalist class interests and entrenched elites). As one scholar has observed, the study of legal consciousness was 'neither attitude nor epiphenomenon, but cultural practice' (Mezey, 2001, p. 151).

Finally, law and society scholarship in recent years has gone global. While there have always been sociolegal scholars outside the United States, sociolegal scholarship had generally been focused on domestic or indigenous legal systems. Interestingly, it may be that law and society ignored international law for the same reason some conservative international relations realists do: because there are few obvious sites of coercive authority or bureaucracies of enforcement (Dickinson, 2007). In addition, some more anthropologically inclined law and society scholars 
may have neglected international law because of their concern for the local (Merry, 2007). But with the increasing proliferation of international and transnational tribunals and the growing recognition that many international institutions significantly impact the economic, environmental, human rights and development climate of the world, law and society scholars have 'discovered' the international. Thus, we now see pluralist perspectives that emphasize the interaction of official and non-official bodies at all levels of the international and transnational system (for example, Berman, 2007a, 2007b; de Sousa Santos and Rodriguez-Garavito, 2005; Rajagopal, 2005), a new interest in international bureaucracies (for example, Riles, 2000; Warren, forthcoming), analyses of how 'local' and 'international' discourses intersect and affect each other (for example, Berman, 2006; Goodale, 2002; Merry and Stern, 2005), studies of the interest group politics at work in international and transnational institutions (for example, Keck and Sikkink, 1998; Pollack and Shaffer, 2001; Warren, forthcoming) and so on.

In short, although we are now in the fifth decade since the founding of the Law and Society Association, the distinctive hallmarks of a law and society approach are even more difficult to describe or define than they were at the start. Indeed, to return to Abel's 'definition', nearly any interpretive lens that looks to the context of law and not just its formal rules can plausibly be called a law and society approach. And though the lack of an overarching methodology can be a flaw (because law and society scholars might not be pushed sufficiently to discuss or develop their methodologies with sufficient rigour), the resulting cacophony can also be liberating, because it recognizes that no one methodology, on its own, will capture the multifaceted ways in which law interacts with society.

In any event, this collection will employ the 'big tent' approach exemplified by Abel. The essays that follow include law professors analysing issues involving online interaction from the perspectives of history, critical theory, cultural studies, anthropology, legal realism and philosophy. In addition, I include authors who probably would not say they are doing legal scholarship at all. But what knits the essays together, I believe, is an understanding that legal doctrine does not exist in a vacuum and that the interaction between law and society is part of the essential study of the emerging field of online regulation.

\section{Cyberspace}

But is 'online regulation' really a discrete field worthy of a separately defined study? After all, mightn't we just talk about a law and society approach to communication of all varieties and just treat online activity as one mode of interaction? And why call it 'cyberspace'? Is there really a distinct space or place involved in online interaction that makes it different from, say, 'telephone space'? If so, are there specific types of legal disputes about online interaction that can be termed 'cyberlaw' disputes or does 'cyberlaw' refer to any dispute with an online component? As it turns out, such questions have been asked from the very first emergence of online interaction into the popular consciousness, circa 1995. Thus, as a first attempt to define cyberspace as a field of inquiry, we might begin by analysing the now longstanding debates within the field, as well as the various scholarly waves that have washed over cyberlaw scholarship during the last ten-plus years.

From the beginning, scholars and judges have questioned whether the world of online interaction really constituted a new area of law or whether instead Internet legal issues could 
be resolved within existing legal paradigms. The most famous early sceptic, US Court of Appeals Judge Frank Easterbrook, provocatively argued that studying cyberlaw as a separate field of study would be no different from studying the 'law of the horse' in the nineteenth century (Easterbrook, 1996). As Easterbrook saw it, horses caused torts, horses were bought and sold, horses were stolen, but all that activity did not necessitate a unique field of study. Rather, he argued, 'general rules' of tort, property, contract or criminal law could easily be applied to horses without the need to invent a new legal regime. Likewise, according to Easterbrook, we can apply general legal principles to online interaction without needing anything called 'cyberlaw'.

Easterbrook's critique and responses to it effectively divided early legal scholarship regarding online communication into two camps. On one side were the cyberspace 'unexceptionalists' who argued in various contexts that the online medium did not significantly alter the legal framework to be applied (for example, Goldsmith, 1998a, 1998b; Stein, 1998). On the other, cyberspace 'exceptionalists' argued that the medium itself created radically new problems requiring new analytical work to be done (for example, Burk, 1996; Johnson and Post, 1996; Post, 2002).

This was a false dichotomy from the start, of course. First, one's perspective on whether the online medium creates a new problem depends in large part on what the legal question is. For example, defamation is generally defined as the communication of a false statement about someone with the requisite degree of intent. This communication can be written or oral, and if it is written, there does not seem to be much of a legal difference whether the written defamation is communicated by postal mail, fax or e-mail. Thus, unexceptionalism seems to apply to defamation law. But when we turn to the question of intermediary liability and ask whether (and under what circumstances) various types of Internet service provider should be held liable for defamatory content accessible through their portals, then we have a question that is not easily answered without some conceptual understanding of what an Internet service provider is or should be. So, online defamation issues require either an exceptionalist or an unexceptionalist approach, depending on whose liability one is discussing.

The second reason the dichotomy was unhelpful from the beginning is that the unexceptionalist position assumes that there actually are well-settled 'general' principles of law that can simply be applied to new legal settings without alteration. And yet it is the nature of law (and especially the common law) that it changes over time. Thus, what is well-settled for one generation (or in one century) is apt to be very different from what is well-settled for the next. Even more importantly, new technologies that alter the culture are precisely the sorts of changes that tend to result in shifts to well-settled legal principles.

For example, in the nineteenth century, 'well-settled' principles of legal jurisdiction saw jurisdiction as rooted almost exclusively in the territorial power of the sovereign. Each sovereign was deemed to have jurisdiction, exclusive of all other sovereigns, to bind persons and things present within its territorial boundaries. By the early twentieth century, growth of interstate commerce and transportation put pressure on the idea that a state's judicial power extended only to its territorial boundary. In particular, the invention of the automobile and the development of the modern corporation meant that far-away entities could inflict harm within a state without actually being present there at the time of a lawsuit. Not surprisingly, by the end of the twentieth century it had become 'well-settled' that a state may indeed assert jurisdiction over a defendant if the effects of the defendant's activities are felt within the 
state's borders, even if the defendant has not literally set foot there. And, of course, this new well-settled rule felt as commonsensical and obvious to most judges, lawyers and observers as the sovereigntist view felt in the nineteenth century.

Now, jurisdictional rules are in flux again, at least in part because of the Internet (Berman, 2002). Indeed, the so-called 'effects doctrine' described above has been difficult to apply to online interaction because material on a website potentially creates effects anywhere the material is viewed. For example, in the celebrated case involving France's efforts to prosecute Yahoo!.com for allowing French citizens to download Nazi memorabilia and Holocaust denial material. It was in some sense perfectly reasonable for France to move against Yahoo! because material available on Yahoo!'s servers created harm in France. Yahoo!, in turn, argued that the French assertion of jurisdiction was impermissibly extraterritorial in scope. According to Yahoo!, in order to comply with the injunction it would need to remove the pages from its servers altogether (not just for the French audience), thereby denying such material to nonFrench citizens, many of whom have the right to access the materials under the laws of their countries. Most importantly, Yahoo! argued that such extraterritorial censoring of American web content would run afoul of the First Amendment of the US Constitution. Thus, Yahoo! and others contended that the French assertion of jurisdiction was an impermissible attempt by France to impose global rules for Internet expression.

Yet, the extraterritoriality charge runs in both directions. If France is not able to block the access of French citizens to proscribed material, then the United States will effectively be imposing First Amendment norms on the entire world. Indeed, we should not be surprised that as the Internet itself becomes less US-centred, a variety of content norms will begin competing for primacy (Reidenberg, 2002). And though geographical tracking software might seem to solve the problem by allowing websites to offer different content to different users, such a solution is probably illusory because it would still require the sites to analyse the laws of all jurisdictions to determine what material to filter for which users.

Addressing the particular jurisdictional conundrum raised by the Yahoo! case (and others) is beyond the scope of this introductory note. Suffice to say that however one resolves the issue, 'well-settled' principles of jurisdictional law are unlikely to be very helpful because such principles are themselves always in flux, often precisely because of the pressures placed on such principles by new communications technologies such as the Internet. Thus, in some sense a pure unexceptionalist position is difficult to maintain.

If unexceptionalists have relied too much on the application of mythical well-settled principles, the exceptionalists have, at times, tended to the opposite extreme, assuming that the rise of cyberspace upended nearly all extant ideas about law and the role of the state. Indeed, many so-called 'enforctarians' rejected the idea that Internet 'communities' could or should be governed by territorially based sovereigns at all. For example, in 1996, John Perry Barlow issued his much-quoted Declaration of Independence of Cyberspace, in which he wrote:

Governments of the Industrial World, you weary giants of flesh and steel, I come from Cyberspace, the new home of Mind. On behalf of the future, I ask you of the past to leave us alone. . . I declare the global social space we are building to be naturally independent of the tyrannies you seek to impose on us. You have no moral right to rule us nor do you possess any methods of enforcement we have true reason to fear. ... Your legal concepts of property, expression, identity, movement, and context do not apply to us. They are based on matter, and there is no matter here (Barlow, 1996). 
Exceptionalist legal scholars were more measured in their rhetoric, but similarly aggressive in their policy prescriptions. Perhaps most provocatively, David Johnson and David Post, echoing Barlow, argued that cyberspace could not legitimately or effectively be governed by territorially based sovereigns and that the online world should create its own legal jurisdiction (or multiple jurisdictions) (Johnson and Post, 1996). In response, others focused on the need for, and legitimacy of, regulation by nation-state sovereigns, pointing to the significant harms that could be caused online and the interest of states in combating those harms (for example, Goldsmith, 1998a, 1998b; Stein, 1998).

These initial debates from the first five or so years of cyberlaw commentary - between exceptionalists and unexceptionalists, cyberlibertarians and nation-state sovereigntists - eventually gave way to a 'second generation' of scholarship. Given the myriad ways in which governments and corporations mobilized to regulate and control online activities, commentators could no longer speak confidently about cyberspace as an inherently unregulatable space, where sovereign governmental entities would be impotent and where newly empowered individuals would force the collapse of all kinds of cultural intermediaries and brokers, from political parties, to media conglomerates, to corporations. At the same time, however, unexceptionalism seemed similarly quaint. By 1998, it was clear that something was going on and that simply holding on to old legal solutions and attempting to paste them onto Internet problems was not a useful strategy either.

Into this environment, the second generation of thinking about the Internet emerged, far less sanguine in its analysis of online regulation and more sober in its discussion of individual empowerment (for example, Boyle, Chapter 7 this volume; Cohen, 1998a; Lessig, 1999; Reidenberg, 1998). Perhaps the most significant observation made by such second-generation theorists concerned the ways in which behaviour may be regulated online. Many of us tend to think of regulation solely as the coercive commands of a sovereign entity. When the legislature passes a law proscribing some behaviour, or an administrative agency establishes rules, or a court issues an order, it is easy to see how such activity regulates behaviour. In contrast, it is more difficult to recognize the powerful way in which our environment and the architecture of our space applies a regulatory force. If one wanted to prohibit automobiles from driving into a public park, for example, one could pass a law forbidding such conduct and then hire police officers to patrol for violations. But one could also simply build walls that make it much more difficult (if not impossible) as a practical matter for the automobile to enter the park in the first place. It is important to realize that both the law and the wall function as regulatory tools.

In cyberspace, this second type of regulation is likely to be more powerful than the first because the 'architecture' of cyberspace is determined by software code, which is infinitely malleable and operates through the technology itself. Thus, in order to limit access to obscene or indecent speech, a sovereign government can try to pass a law banning such speech, but the government is likely to encounter enforcement problems. Such problems might include the difficulty of tracking down online perpetrators - particularly those who disguise their identities - and the possibility that an offender is from a different jurisdiction, rendering him beyond the regulatory reach of the enforcing government. Indeed, as noted previously cyberlibertarians initially proclaimed the online world an inherently unregulatable space precisely because of these types of problems. A government is not limited to this style of regulation, however. Instead, it can create (or encourage the creation of) filters that will effectively 'zone' cyberspace into areas that can be entered only by those possessing certain qualifications - a credit card, 
for example, or an adult identification number. This 'code-based' regulation is potentially far more efficient - and therefore far more powerful - than a coercive command issued by a sovereign because the enforcement mechanism is embedded in the technological architecture itself. Thus, as James Boyle observes in Chapter 7, the 'Austinian' positivist model of the lumbering state, regulating through its unwieldy apparatus of power, is being replaced in cyberspace by a model of power more akin to that envisioned by Michel Foucault, where coercion is so much a part of the landscape that we often fail even to recognize it.

Moreover, not only sovereign governments, but also private entities can wield this codebased power. If an access screen requires a user to click ' $\mathrm{OK}$ ' to contractual terms, and those terms obligate the reader to pay a dollar per page viewed at a given website, then the dollar fee becomes the 'law' of that website, even if the copyright law would have permitted the use for free. Similarly, if America Online or Google wishes to censor a user's speech, it can simply eliminate the user's online privileges or remove the user's website from its search indexes, regardless of whether the First Amendment would protect that speech. And, perhaps most importantly, because the technical standard-setting bodies of cyberspace are nongovernmental, they may face no real oversight at all (Froomkin, 2000; Weiser, 2001). Thus, scholars resurrected legal realist arguments about how private entities, in concert with state enforcement of property and contract law, would effectively regulate (and control) a space that had at first seemed unregulatable (for example, Cohen, 1998b; Radin, Chapter 6).

This sceptical (and perhaps even dystopian) second generation focused on cyberspace not as a place of freedom but as one increasingly of control. We were reminded of how many of the freedoms we take for granted exist simply because, in the physical world, certain forms of regulation or invasion of privacy are impossible or impractical. Thus, for example, it would be difficult to track customers in a shopping centre to catalogue each product that every customer so much as looks at. But such tracking of browsed items is trivially easy online (Kang, 1998). Likewise, it would be prohibitively expensive for content providers to install censors in every library photocopy machine to trace copyright violations. But again such traceability is potentially built into every download. As a result, so the dystopian vision would have us believe, the online world is one where freedom is curtailed, content is distributed only for a fee, privacy is non-existent and private filters limit access to information (Lessig, 2001). Moreover, that same technology might even threaten to derail political discourse because every person's news will be filtered through self-imposed blinkers imposed using pre-determined criteria selected by the individual (for example, Sunstein, 2001). In such a world, the important role of the state as a locus for debate and collective decision-making (assuming it ever played such a role) is undermined.

Now, it seems that we may have reached a third generation of scholarship which, perhaps not surprisingly, is merging some of the perspectives of the previous two (for example, Benkler, 2006; Johnson, Crawford and Palfrey, 2004; Zittrain, 2006). Like the exceptionalists, these scholars believe that there is something profoundly different about cyberspace that opens up new spheres of connection, generates new opportunities for creativity and potentially alters political economies and cultural politics. At the same time, like that of the second generation, the new scholarship is preoccupied with questions of technical architecture and private power. The result is a focus on how to maintain the Internet as a place where users - separately and collectively - retain the ability to develop infinite adaptations and innovations. These scholars take seriously the idea that the architecture of cyberspace is infinitely malleable and 
that the forces of greater control have a vested interest in turning the Internet into something more resembling a series of connected appliances with specifically delimited functionality (think TiVo machines) than a truly free-wheeling generative space (Zittrain, 2006). Thus, these scholars seek structural ways to imbed more generative architecture, and they analyse the variety of ways in which networks of users resist regulatory efforts through the use of technology.

Having briefly surveyed these trends in scholarship over the last decade, we are perhaps in a better position to answer the questions with which we began: Does 'cyberlaw' encompass every legal issue having to do with online interaction? And is it even useful to think about 'cyberlaw' as a distinct field of inquiry? As to the first question, the answer seems clearly to be 'no'. The unexceptionalists are undoubtedly right that there are many issues involving online activities that do not require new paradigms to resolve them. Indeed, to the extent that the Internet is functioning only as the medium of communication without changing the framework underlying the legal question at issue, then we can plausibly exclude that legal question from the category of 'cyberlaw'.

The second question requires more explanation, but the underlying idea reflected in the title of this volume is that, yes, 'cyberlaw' really is something important and distinct, and therefore worth studying on its own. In part, this is simply because the Internet has unsettled a whole host of legal doctrines, and a time of flux is also a time of opportunity. As judges, legislators and scholars struggle to apply old legal principles to new contexts, they are - in a far more self-conscious way than usual - questioning whether those old legal principles really work in the brave new world they are encountering. Such a time of self-conscious inquiry opens the conceptual space to allow one to go back to first principles and ask important jurisprudential and sociologically charged questions that run throughout all of law. Thus, we can productively view many dilemmas of legal doctrine, jurisprudence and social context through the lens provided by cyberlaw.

In addition, thinking of 'cyberlaw' as a whole, rather than as a discrete series of legal doctrines applied to online interaction, allows one to see important structural patterns. It is not an accident that each of the three waves of scholarship described above takes a structural approach, emphasizing large-scale cultural, economic, political and legal forces that are more fundamental than just how particular legal rules will apply to particular sorts of interactions. The study of cyberlaw encourages such macro-theorizing. And again, the insights gained will undoubtedly apply to law and society more generally, and not just online interaction.

Finally, for anyone interested in sociolegal scholarship, studying cyberlaw provides a wonderful case study of law and culture turning like a mobius strip, one into each other. Consider the sequence. Legal regulation and governmental institutions provide a context for technological innovation concerning online interaction. Then, the Internet explodes into the popular imagination far more than anyone could have dreamed. Then, law tries to catch up, technical architecture begins to function as a form of law, nation-states struggle to craft enforceable legal rules with bite and this variety of legal and quasi-legal regulation proliferates, changing the online experience in fundamental ways (compare people's ideas of online community in 1995 with those in 2005). But then new social forms - such as peer-topeer file-sharing, blogging, YouTube, MySpace and so on - emerge to upset the new efforts to control behaviour, and the mobius strip turns again. And of course, this linear sequence is not truly linear at all, as the legal and the social interpenetrate at every stage. 
This is a veritable treasure trove for law and society scholars seeking the variety of ways law shapes and is shaped by the interactions we collectively term the 'social'. Moreover, in cyberlaw we find all of the quintessential law and society debates - about law on the ground vs. law in action, the role of entrenched economic power, the importance of embedded (though often invisible) legal regimes, the ubiquitous (though again often invisible) role of the state, the significance of non-state communities to the construction of norms, the role of globalization - played out in a context where people are ready and willing to think reflectively and embrace new ideas and alternative paradigms. Thus, of all the ways cyberlaw can be viewed, one particularly fruitful way is as a law and society laboratory. The rest of this book is devoted to surveying some of this new and exciting 'laboratory' work.

\section{The Essays}

The collection begins with a consideration of the interaction between communications revolutions and societal change. As discussed above, it is difficult to rely on settled legal principles to resolve online disputes because communications revolutions can unsettle the very legal principles being applied. Sherry Turkle, a professor in the sociology of science, was one of the first academics to consider the psychological and sociological impact of online interaction in her groundbreaking book, Life on the Screen: Identity in the Age of the Internet (1995). In that book, and in the short essay included as Chapter 1 in this volume, Turkle argues that the very way in which we think - the metaphors, the cognitive categories, the narratives we employ - are affected by the dominant technologies of the era. Thus, just as the vast machinery of the industrial revolution became the prototype for modernist thought - with its emphasis on mechanics, industrial production and assembly and disassembly - Turkle suggests that the computer is the technology of postmodernism, a world of surfaces, simulation and flexible identity. Indeed, it is interesting to consider the extent to which 'webs' have become a dominant trope for thinking about today's world, whether they are used as a way to chart multinational corporate activity, transnational legal regulation or global terrorism. Network theory itself is a creature of the rise of online interaction, both because the Internet facilitates the creation of networks and because it provides a set of metaphors and 'test objects' for thinking in terms of networks. And, as Turkle points out, the rise of computers affects our understanding of what it means to be human, how the brain works, what privacy means and a myriad of other micro- and macro- social and psychological changes. Thus, Turkle's essay, though it does not specifically mention law, provides a useful introduction to any consideration of how the cognitive categories of law might be affected by the rise of new technologies.

Richard Ross' contribution (Chapter 2) then offers a historical perspective on similar questions, considering the impact of the printing press on legal culture. Such a study, Ross argues, should complicate accounts that assume new technologies will simply affect legal culture in a unidirectional way. Rather, Ross suggests that a more contextual approach is required, one that analyses what he calls 'conjunctive causation'. In this approach, we would understand that the impact of new communications technologies always depends on their interaction with variable sets of background conditions within narrowly defined local contexts. Accordingly, we cannot simply assume that 'the Internet changes everything' without a set of grounded analyses of how the rise of online communication interacts with pre-existing local political, social and economic dynamics. 
Although Turkle's essay touches on the idea of the computer as a metaphor, in Chapter 3 Dan Hunter more explicitly takes up the role of metaphor in legal regulation of online interactions. Specifically, Hunter explores the impact of thinking about 'cyberspace' as a place and the use of a variety of spatial metaphors for describing the online experience. According to Hunter, such thinking has tended to push both judges and scholars towards legal regimes that overly 'propertize' online interaction, importing metaphors of trespass and private property to realms where they arguably create perverse results. Hunter's analysis therefore demonstrates the importance of the law-society tie: the metaphors that become common parlance for describing some activity inevitably influence the legal rules developed to regulate that activity, and vice-versa. Given that the use of metaphor is both an inevitable part of human cognition and a fundamental part of the common law legal process, this is an important insight indeed. And, as Ross would remind us, the particular metaphor chosen is itself influenced by political and economic interest, in this case a libertarian capitalist ideology of unfettered private enterprise.

The next two contributions consider the relationship between online interaction and globalization. Since the end of the Cold War, the terms 'cyberspace' and 'globalization' have become buzzwords of a new generation. And it is probably not surprising that the two entered the lexicon almost simultaneously. From its beginning, the Internet heralded a new world order of interconnection and decentralization, while the word 'globalization' conjured for many the spectre of increasing transnational and supranational governance as well as the growing mobility of persons and capital across geographical boundaries. Thus, both terms have reflected a perception that territorial borders might no longer be as significant as they once were. Social theorist Gunther Teubner has been discussing global law beyond the state for many years, so it is not surprising that he would latch on to cyberspace as a site for considering non-state-based constitutionalism. Continuing to build from Niklas Luhmann's work (for example, Luhmann, 1995) emphasizing the importance of autonomous social systems, rather than just states, Teubner (Chapter 4) sees the state as only one law-making force among many. My essay in this volume (Chapter 5) similarly seeks to deprivilege the idea of nation-state legal jurisdiction defined by reified territorial boundaries and physical location. Instead, I advocate a cosmopolitan approach that seeks to steer a middle ground between territorialism and universalism. I believe that, although people often associate cosmopolitanism with utopian universalism, a more nuanced account of cosmopolitan theory takes seriously people's multiple community attachments: local, global and non-territorial. And I use this cosmopolitan approach to analyse the sorts of cross-border legal issues that are increasingly common in an era of online interaction.

Whereas globalization is a relatively recent academic trope, legal realism has a pedigree going back to the beginning of the twentieth century. Moreover, as noted above, legal realism was one of the important progenitors of the law and society movement itself. So, what does legal realism have to contribute to a discussion of cyberspace? As the essays by James Boyle and Margaret Jane Radin make clear, a legal realist perspective offers a response to cyberlibertarians who see the Internet's nature as inherently pushing in the direction of more individual liberty. In Chapter 6 Boyle challenges the claim that states will inevitably wield less power over the online environment, and he points out ways in which the government can embed power into the technical architecture of the Internet itself. In Chapter 7 Radin focuses on the problem of private - rather than state - power, noting that the use of online contracts 
backed by technological protection measures can effectively replace the balances struck by, say, copyright law with the 'law of the firm'. Radin therefore, like her legal realist forebears, emphasizes the ways in which private power relies on state enforcement of background contract and property regimes, rendering the line between 'public' and 'private' ordering murky at best.

Lawrence Lessig and Jack Balkin, in their discussions of freedom of expression, are similarly concerned about threats to freedom posed by private, and not just state, power. In Chapter 8 Lessig even goes so far as to argue that regimes in which the government would create 'zoning' rules to regulate speech would actually be preferable to the widespread use of private speech filters. This is primarily because speech filtering can take place at the service provider, browser or search engine level and therefore can occur without users even knowing about it. Significantly, Lessig focuses almost exclusively on the amount of speech regulated and cares much less about who does the regulating: private entities or the state. This is a paradigm shift from the traditional 'rights against the state' model of free speech constitutionalism, whereby the principal target of concern is government censorship. In Chapter 9 Balkin similarly focuses on corporate as well as state impingements on free expression. But Balkin argues that digital technologies alter the social conditions of speech and therefore should change the touchstone of free speech theory altogether. Thus, instead of training the First Amendment gaze only on how to foster democratic participation in political discourse, he suggests that we should turn our attention to how we can best provide individuals with the means to participate in the production and distribution of culture.

In this domain of culture, freedom of expression sits in an uneasy relationship with copyright law because copyright law effectively censors speech in the name of providing incentives to create. The essays by Jane C. Ginsburg and Jessica Litman offer differing approaches to copyright issues in cyberspace. Ginsburg, in Chapter 10, argues that we need to strengthen authorial control over digital distribution of creative works. According to Ginsburg, such increased authorial control is most likely to provide the incentives necessary to give the public access to more (and more widely varied) material. In Chapter 11 Litman, in contrast, argues that the current copyright regime only makes sense in a world where most means of mass dissemination required investments in printing presses, distribution networks, broadcast towers and so on. In such a world, she suggests, we may have needed to ensure that publishers and distributors received money through strong copyright protection. However, according to Litman, we are now in a world where what she calls 'untamed anarchic digital sharing' through peer-to-peer networks is demonstrating itself as a superior distribution mechanism, or at least a useful adjunct to conventional distribution. If that is the case, Litman argues, we ought to encourage the new form of distribution rather than use strong authorially based copyright protection to stifle it. In the contrasting positions of Ginsburg and Litman, we see the 'exceptionalist'/'unexceptionalist' debate play out, with Ginsburg arguing for application of standard copyright principles to a new medium, and Litman advocating a new paradigm altogether.

Privacy is another area where the information processing and data storage capability of the online world threatens to upend established paradigms. Indeed, the entire idea of 'informational privacy' has in some respects replaced traditional privacy concerns about surveillance as the principal subject of debate. And, as in the works of Radin, Lessig and Balkin, Julie Cohen's essay on informational privacy (Chapter 12) focuses on threats to freedom posed by non-state 
actors, in this case the many corporations amassing huge stores of searchable data. Moreover, Cohen rejects the 'consent' model usually used to address issues of data privacy, whereby users are given 'freedom of choice' to opt in to or opt out of data collection activities. To Cohen, such a formulation does not do justice to individual autonomy, because it renders individuals simply the objects of choices created by others. Instead, Cohen argues that protections for data privacy should be grounded in an appreciation of the conditions necessary for individuals to develop and exercise autonomy.

A focus on personal autonomy also leads naturally to questions of community identity and membership because arguably autonomy implies both the ability to connect with others and the ability to choose from a number of flexible affiliations. The final two sections of this collection address issues of cyberspace, personal identity and the formation of community. Even before the idea of online communication entered the popular consciousness, online devotees and scholars of the Internet were considering the implications of 'virtual worlds' or 'virtual communities'. In the early days of the Internet, this meant studies of online chatrooms and primitive text-based role-playing spaces known as MUDs or MOOs. Now, the debate has shifted to the use of the Internet by potentially marginalized communities and the increasingly lucrative sphere of multiplayer simulated worlds. The four essays that conclude the volume variously ponder these issues of identity and community and their relationship to law.

Anupam Chander and Jerry Kang consider the effect of the Internet on racial and ethnic minorities. In Chapter 13 Chander responds to concerns that the Internet will cause cultural fragmentation by allowing individuals to insulate themselves from competing views, which, so the argument goes, will make it more difficult for societies to inculcate shared understandings of reality. According to Chander, any such assimilationist longing for shared understandings ignores the significance of the Internet as an engine for multiculturalism. Chander argues that cyberspace empowers minority groups by allowing them to create transnational communities of interest, ethnic identity, religious belief or other affiliation. Chander suggests that such transnational bonds may help give members of minority groups a fuller sense of citizenship, what he describes as 'a right to a practice of citizenship that better reflects who they are'.

Kang strikes a similarly optimistic note in Chapter 14, arguing that online interaction, because it allows racial anonymity and pseudonymity, could fundamentally alter the social context for racial politics in the United States (and presumably elsewhere). Kang argues that, because racial identification is mostly invisible in the online environment (at least until video overtakes text as the dominant means of online self-presentation), three important results are likely to follow: (1) racial mapping will be undermined by pervasive online racial anonymity; (2) increased interracial social interaction will foster racial integration; and (3) the increased ability to 'pass' as a member of another race will destabilize the significance of racial categories altogether.

The dark side of both Chander's and Kang's visions, of course, is the possibility of increased self-segregation and the empowerment of illiberal thought through international cybernetworking. Indeed, if the rise of online interaction enables minority groups to combat isolation by linking with others, as Chander argues, then it also enables lonely extremists to find a welcoming transnational community that may encourage violently racist or sectarian beliefs. Likewise, while the erasure of race online offers opportunities for changing social attitudes in a more inclusive direction, the existence of illiberal sites may help to amplify, inculcate and encourage exclusionary (or even violent) beliefs. The inevitable conclusion is 
that cyberspace is virgin social space, and as such it inevitably offers both promise and peril, as it reflects and transforms the social life that migrates there.

As noted above, such cyber social life includes the creation of alternative communities. And the development of these communities inevitably raises questions about the legal rules that should govern such communities. Are they, after all, their own legally defined communities exercising their own forms of governance, jurisdiction and sanction? Or are these communities simply elaborate games to be governed either by the game creator or by the sovereign that exercises authority over the players as they sit in their (territorially delimited) chairs in front of computer screens across the globe? The final section considers such questions. In Chapter 15 Jennifer Mnookin describes a notorious 'cyber-rape' in an early online community, LambdaMOO, as well as the group's efforts to build a fledgling governance structure to address online misbehaviour. Fast-forwarding a decade or so, James Grimmelmann, in Chapter 16 , looks at legal/governance issues in the new generation of multiuser game communities. Grimmelmann even goes so far as to suggest that we think of virtual worlds as alternative legal systems and thereby analyse them through the lens of comparative law.

This discussion returns us full circle to the original cyberlaw debates between exceptionalists and unexceptionalists. In the end, nearly all of the essays in this collection suggest that the rise of cyberspace has fundamentally altered sociolegal reality. Whether they are discussing how people think, how globalization affects legal analysis, how public and private power is deployed online, how debates about free speech, copyright and privacy are reconfigured by the rise of the Internet or how concepts of racial, ethnic or community identity may shift, most of the authors in this volume seem to believe that something is changing.

Perhaps that is to be expected. After all, if one takes a law and society approach, one cannot look at 'well-settled' legal principles in a vacuum or rely on such principles to orient oneself in the social world. Instead, law and society scholarship has always opened up the black box of legal doctrine to let the messy on-the-ground realities pervade the discussion. And once such realities are part of the analytical framework, it becomes nearly impossible to insist that the extraordinary social changes wrought by the Internet would not have an effect on legal doctrine (though, as Ross cautions, those effects are never unidirectional nor are they uninfluenced by pre-existing political and economic power and interest). Thus, if there's one thing that a law and society approach to cyberspace suggests it is that cyberspace is in fact worth studying as a sociolegal phenomenon in its own right, a phenomenon whose myriad affects and dislocations we are only just beginning to perceive.

\section{References}

Abel, Richard L. (1995), 'What We Talk About When We Talk About Law', in Richard L. Abel (ed.), The Law and Society Reader, New York: New York University Press, pp. 1-10.

Barlow, John Perry (1996), 'A Declaration of the Independence of Cyberspace', <http://www.eff. org/ barlow/Declaration-Final.html $>$.

Benkler, Yochai (2006), The Wealth of Networks: How Social Production Transforms Markets and Freedom, New Haven, CT: Yale University Press.

Berman, Paul Schiff (2002), 'The Globalization of Jurisdiction', University of Pennsylvania Law Review, 151, pp. 311-529. 
Berman, Paul Schiff (2006), 'Seeing Beyond the Limits of International Law', Texas Law Review, 84, pp. 1265-306.

Berman, Paul Schiff (2007a), 'A Pluralist Approach to International Law', Yale Journal of International Law, 32, p. 301-29.

Berman, Paul Schiff (forthcoming 2007b) , 'Global Legal Pluralism', Southern California Law Review, 80.

Blumberg, Abraham S. (1967), 'The Practice of Law as Confidence Game: Organizational Cooptation of a Profession', Law and Society Review, 1, pp. 15-39.

Bohannan, Paul (ed.) (1967), Law and Warfare: Studies in the Anthropology of Conflict, Garden City, NY: The Natural History Press.

Burk, Dan L. (1996), 'Federalism in Cyberspace', Connecticut Law Review, 28, 1095-136.

Cohen, Julie E. (1998a), 'Intellectual Privacy and Censorship of the Internet', Seton Hall Constitutional Law Journal, 8, p. 693-701.

Cohen, Julie E. (1998b), 'Lochner in Cyberspace: The New Economic Orthodoxy of "Rights Management"', Michigan Law Review, 97, pp. 462-563.

Cohen, Julius, Robson, Reginald A. and Bates, Alan (1958), Parental Authority: The Community and the Law, New Brunswick, NJ: Rutgers University Press.

Collier, Jane (1975), 'Legal Processes', Annual Review of Anthropology, 4, pp. 121-44.

de Certeau, Michel (1984), The Practice of Everyday Life, trans. Steve Rendell, Berkeley, CA: University of California Press.

de Sousa Santos, Boaventura and Cesar A. Rodriguez-Garavito (eds) (2005), Law and Globalization from Below: Towards a Cosmopolitan Legality, New York: Cambridge University Press.

Dickinson, Laura A. (2007), 'Introduction' in Empirical Approaches to International Human Rights, Aldershot: Ashgate Publishing Limited.

Durkheim, Emile (1964), The Division of Labor in Society, New York: Free Press.

Durkheim, Emile (1973), ‘Two Laws of Penal Evolution', Economy and Society, 2, pp. 278-84.

Easterbrook, Frank H. (1996), 'Cyberspace and the Law of the Horse', University of Chicago Legal Forum, pp. 207-216.

Ewick, Patricia and Silbey, Susan S. (1998), The Common Place of Law: Stories from Everyday Life, Chicago, IL: University of Chicago Press.

Feeley, Malcolm (1977), The Process is the Punishment, New York: Russell Sage Foundation.

Foucault, Michel (1980), Power/Knowledge: Selected Interviews and Other Writings, 1972-1977, ed. Colin Gordon, New York: Pantheon Books.

Froomkin, A. Michael (2000), 'Wrong Turn in Cyberspace: Using Icann to Route around the APA and the Constitution', Duke Law Journal, 50, pp. 17-184.

Frug, Gerald E. (1984), 'The Ideology of Bureaucracy in American Law', Harvard Law Review, 97, pp. 1276-1388.

Frug, Mary Joe (1985), 'Re-reading Contracts: A Feminist Analysis of a Contracts Casebook', American University Law Review, 34, pp. 1065-1140.

Goldsmith, Jack L. (1998a), ‘Against Cyberanarchy’, University of Chicago Law Review, 65, pp. 422-30.

Goldsmith, Jack L. (1998b), 'The Internet and the Abiding Significance of Territorial Sovereignty', Indiana Journal of Global Legal Studies, 5, pp. 485-86.

Goodale, Mark (2002), 'Legal Ethnography in an Era of Globalization: The Arrival of Western Human Rights Discourse to Rural Bolivia', in June Starr and Mark Goodale (eds), Practicing Ethnography in Law: New Dialogues, Enduring Methods, New York: Palgrave Macmillan, pp. 50-72.

Gordon, Robert W. (1984), 'Critical Legal Histories', Stanford Law Review, 36, pp. 57-125. 
Gramsci, Antonio (1971), Selections from the Prison Notebooks of Antonio Gramsci, trans. Quintin Hoare and Geoffrey Newell Smith, London: Lawrence and Wishart.

Hirst, Paul Q. (1972), 'Marx and Engels on Law, Crime, and Morality', Economy and Society, 1, pp. 28-55.

Hoebel, E. Adamson and Karl Llewellyn (1941), The Cheyenne Way, Norman, OK: University of Oklahoma Press.

Hunt, Alan (1978), The Sociological Movement in Law, London: Macmillan.

Johnson, David R., Crawford, Susan P. and Palfrey, John G. Jr (2004), 'The Accountable Internet: Peer Production of Internet Governance', Virginia Journal of Law and Technology, 9, pp. 133.

Johnson, David R. and Post, David G. (1996), 'Law and Borders - the Rise of Law in Cyberspace', Stanford Law Review, 48, pp. 1367-1402.

Kairys, David (ed.) (1982), The Politics of Law: A Progressive Critique, New York: Pantheon.

Kalven, Harry Jr and Zeisel, Hans (1966), The American Jury, Chicago, IL: University of Chicago Press.

Kang, Jerry (1998), 'Information Privacy in Cyberspace', Stanford Law Review, 50, pp. 1212-20.

Keck, Margaret E. and Sikkink, Kathryn (1998), Activists Beyond Borders: Advocacy Networks in International Politics, Ithaca, NY: Cornell University Press.

Kelman, Mark (1987), A Guide to Critical Legal Studies, Cambridge, MA: Harvard University Press.

Kennedy, Duncan (1976), 'Form and Substance in Private Law Adjudication', Harvard Law Review, 89, pp. 1685-1778.

Lessig, Lawrence (1999), Code and Other Laws of Cyberspace, New York: Basic Books.

Lessig, Lawrence (2001), The Future of Ideas: The Fate of the Commons in a Connected World, New York: Random House.

Luhmann, Niklas (1995), Social Systems, trans. John Bednarz, Jr and Dirk Baecker, Stanford, CA: Stanford University Press.

Maine, Henry Sumner (1861), Ancient Law, New York: H. Holt.

Merry, Sally Engle and Stern, Rachel E. (2005), 'The Female Inheritance Movement in Hong Kong: Theorizing the Local/Global Interface', Current Anthropology, 46, pp. 387-409.

Mezey, Naomi (2001), 'Out of the Ordinary: Law, Power, Culture, and the Commonplace', Law and Social Inquiry, 26, pp. 145-67.

Montesquieu, Charles de Secondat, Baron de (1756), The Spirit of Laws, London: J. Nourse and P. Vaillant.

Moore, Sally Falk (1969), 'Law and Anthropology' in B. Siegel (ed.) Biennial Review of Anthropology, Stanford, CA: University Press, pp. 52-300.

Moore, Underhill and Callahan, C.C. (1944), 'Law and Learning Theory: A Study in Legal Control', Yale Law Journal, 53, pp. 1-136.

Nader, Laura (1965), 'Choices in Legal Procedure: Shia Moslem and Mexican Zapotec', American Anthropologist, 67, pp. 394-99.

Packer, Herbert (1968), The Limits of the Criminal Sanction, Stanford, CA: Stanford: University Press.

Parsons, Talcott (1966), Societies: Evolutionary and Comparative Perspectives, Englewood Cliffs, NJ: Prentice-Hall.

Peltason, Jack (1955), Federal Courts in the Political Process, Garden City, NY: Doubleday Books.

Pollack, Mark A. and Shaffer, Gregory C. (eds) (2001), Transatlantic Governance in the Global Economy, Lanham, MD: Rowman and Littlefield. 
Post, David G. (2002), ‘Against “Against Cyberanarchy”, Berkeley Technology Law Journal, 17, pp. 1-23.

Pound, Roscoe (1910), 'Law in Books and Law in Action: Historical Causes of Divergence between the Nominal and Actual Law', American Law Review, 44, pp. 12-34.

Rajagopal, Balakrishnan (2005), 'The Role of Law in Counter-Hegemonic Globalization and Global Legal Pluralism: Lessons from the Narmada Valley Struggle in India', Leiden Journal of International Law, 18, pp. 345-87.

Redfield, Robert (1964), 'Primitive Law', University of Cincinnati Law Review, 33, pp. 1-22.

Reidenberg, Joel R. (1998), 'Lex Informatica: The Formulation of Information Policy Rules through Technology', Texas Law Review, 76, pp. 553-85.

Reidenberg, Joel R. (2002), 'Yahoo and Democracy on the Internet', Jurimetrics Journal, 42, pp. 261-280

Riles, Annelise (2000), The Network Inside Out, Ann Arbor, MI: University of Michigan Press.

Rose, Arnold M. and Press, Arthur E. (1955), 'Does the Punishment Fit the Crime? A Study in Social Evaluation', American Journal of Sociology, 61, pp. 247-59.

Savigny, Frederick Charles von (1831), Of the Vocation of Our Age for Legislation and Jurisprudence, trans. Abraham Hayward, London: Littlewood.

Schmidhauser, John R. (1960), The Supreme Court: Its Politics, Personalities and Procedures, New York: Holt, Rinehart and Winston.

Schubert, Glendon (1965), Judicial Policy-Making: Political Role of Courts, Chicago, IL: Scott Foresman.

Silbey, Susan S. (1992), 'Making a Place for Cultural Analysis of Law', Law and Social Inquiry, 17, pp. 39-48.

Stein, Allan R. (1998), 'The Unexceptional Problem of Jurisdiction in Cyberspace', International Lawyer, 32, 1167-191.

Sunstein, Cass R. (2001), Republic.com, Princeton, NJ: Princeton University Press.

Tönnies, Ferdinand (1963), Community and Society, trans. Charles H. Loomis, New York: Harper and Row (first published 1887).

Turkle, Sherry E. (1995), Life on the Screen: Identity in the Age of the Internet, New York: Simon and Schuster.

Unger, Roberto (1983), 'The Critical Legal Studies Movement', Harvard Law Review, 96, pp. 563675.

Warren, Kay B. (forthcoming), Human Trafficking, Global Solutions, and Local Realities across the Pacific Rim.

Weber, Max (1978), Economy and Society: An Outline of Interpretive Sociology, trans. Guenther Roth and Claus Wittich, Berkeley, CA: University of California Press.

Weiser, Philip J. (2001), 'Internet Governance, Standard Setting, and Self-Regulation', Northern Kentucky Law Review, 28, pp. 825-826.

Zittrain, Jonathan (2006), 'The Generative Internet', Harvard Law Review, 119, p. 1975-2040. 


\section{Name Index}

Abbott, Andrew 25

Abel, Richard L. xi, xiii, 23-4

Alderson, Arthur S. 46

Amour, Jody 577

Aristotle 82-3

Austin, John 274, 279

Baker, C. Edwin 482-3, 514-15

Balkin, Jack M. xxi, xxii, 266, 325-82

Barlow, John Perry xv, xvi 74-5, 254, 256, 257

Bates, Alan xii

Beale, Joseph 189, 190-95, 201, 205, 212, 214

Benkler, Yochai xvii, 515

Bentham, Jeremy 260

Berliner, Samuel III 432

Berman, Paul Schiff xiii, xv, xx, 169-232

Berners-Lee, Tim 556-7, 559

Black, Max 88-9, 94

Blumberg, Abraham xii

Bohannan, Paul xi

Bollen, Kenneth A. 46

Boyle, James xvi, xvii, xx, 66, 92, 120, 136, 251-79, 515

Bradley, Joseph P. 115

Brand, Stewart 256

Brandeis, Louis D. 393, 544

Breyer, Stephen 229

Brilmayer, Lea 193-4

Brooks, C.W. 29

Bulliet, Richard W. 26

Burk, Dan L. xiv, 10, 107

Callahan, C.C. xii

Cardozo, Benjamin N. 65, 89, 220

Carey, James W. 15

Carrington, Paul D. 10

Chander, Anupam xxii, 210, 541-62

Chartier, Roger 28

Cichanowski, Tommy 432-3

Clinton, William J. 267, 269, 276

Cohen, Julie E. xvi, xvii, xxii, 473-538

Cohen, Julius xii
Collier, Jane xi

Collins, Ronald K.L. 9 passim

Cover, Robert 645

Crawford, Susan P. xvii

Cromartie, Alan 30

Culkin, John 22

Currie, Brainerd 189, 195-8, 200-202, 205, 214

Curtis, Pavel 652-3

Dalehite, Jeff 432

Darwin, Charles 257

Davies, John 30

Dawkins, Richard 257

Delgado, Richard 266

Derrida, Jacques 156

de Certeau, Michel xii

de Sola Pool, Ithiel 18

de Sousa Santos, Boaventura xiii

Dewey, John 544

Dibbell, Julian 736

Dicey, A. 158

Dickinson, Laura A. xii

Dinwoodie, Graeme 183, 203-4, 206

Dogan, Mattei 45

Durkheim, Emile xi, 47

Easterbrook, Frank H. xiii, xiv

Edelman, Peter 512

Eisenberg, Rebecca 131

Eisenstein, Elizabeth L. 33

Ellickson, Robert 712

Emerson, Thomas 329

Entwisle, Barbara 46

Ewick, Patricia xii

Febvre, Lucien 33

Feeley, Malcolm xii

Finnegan, Ruth 19, 37

Fischer-Lescano, Andreas 214

Fisher, Terry 453, 454, 458, 459, 464

Fisher, William W. III 10

Fiss, Owen 266 
Foner, Eric 500

Foucault, Michel xii, xvii, 258-62, 272, 274, 278, 279

Frankfurter, Felix 264

Frendeis, John P. 43

Froomkin, A. Michael xvii

Frug, Gerald E. xii

Frug, Mary Joe xii

Furet, Francois 34

Gardiner, Patrick 37

Gervais, Daniel 454, 458, 459

Gey, Steven 111

Gibson, William 93

Gilder, George 254

Gilmore, John 252

Ginsberg, Elaine 613

Ginsburg, Jane C. xxi, 385-419

Gluckman, Max 24

Godwin, Mike 317-18

Goffman, Erving 527

Goldsmith, Jack L. xiv, xvi, 69-70, 733

Goldstone, David 110

Goodale, Mark xiii

Goodrich, Peter 30

Goody, Jack 15, 16, 17, 19, 37, 41

Gordon, Robert W. xii

Gouldner, Alvin W. 14

Graff, Harvey J. 14, 33, 34, 37

Gramsci, Antonio xii

Gray, Charles 30

Griffin, Jasper 731

Grimmelmann, James xxiii, 703-40

Grotius 156

Habermas, J. 35

Halberstam, Daniel 514-15, 519

Hamidi, Ken 105, 108

Hardin, Garrett 122, 129

Hardy, I. Trotter 10

Hart, H.L.A 37, 156, 163

Heller, Michael 122, 129-31, 133

Hibbitts, Bernard J. 10, 18

Hirst, Paul Q. xi

Hobbes, 243

Hoebel, E. Adamson xi

Hoffman, David 32

Holmes, Oliver Wendell 394, 395, 419

Honore, Tony 37

Huber, Peter 255
Hunt, Alan xi, xii

Hunter, Dan xx, 59-139, 705, 723

Innis, Harold 14, 15, 16, 17, 19, 41

Jefferson, Thomas 256, 257

Jepson, Bill 584, 585

Johnson, David R. xiv, xvi, xvii, 10, 67-8, 118, 119,733

Johnson, Mark 83-4, 89

Judson, Margaret A. 30

Juenger, Friedrich 189, 203

Kairys, David xii

Kalven, Harry Jr. xii

Kang, Jerry xvii, xxii, 563-641

Kant, Immanuel 145, 523

Kapor, Mitchell 74-5

Katsh, M. Ethan 9 passim

Keck, Margaret xiii

Kelman, Mark xii

Kelsen, H. 156

Kennedy, Duncan xii

King, Martin Luther Jr 588

Koster, Raph 723-4, 725

Kraut, Robert 607-8

Kroker, Arthur 15

$\mathrm{Ku}$, Raymond 453, 458, 459

Lakoff, George 79, 89-91, 94, 107, 136

Langdell, Christopher Columbus 32

Lastowka, Greg 705, 723

Lemley, Mark 92-3

Lessig, Lawrence xvi, xvii, xxi, xxii, 10, 20, 117-18, 123, 168, 283-324, 454, 458, $459,499,501$

Levi, Edward H. 22

Lieberson, Stanley 46, 47

Lien, Molly Warner, 10

Lijphart, Arend 43

Litman, Jessica xxi, 247, 421-70

Llewellyn, Karl xii

Locke, John 82, 83, 481, 493, 732

Lucas, George 332

Luhmann, Niklas xx, 156

Lunny, Glynn 454, 458, 459

MacCulloch, Diarmaid 31

McDougal, Luther 189, 203

Mackie, J.L. 37 
McLuhan, Marshall 14 passim

Madison, James 543, 544, 552, 555

Mahoney, James 47

Maine, Henry Sumner xi, 718

Mann, Bruce H. 24

Markell, Bruce A. 18

Markey, Edward J. 269, 276

Martin, Henri-Jean 33

Martin, Peter W. 10, 37

Marx, Karl xi, 339, 541, 579, 648

Meiklejohn, Alexander 325, 353, 356, 364, 366-7

Merry, Sally Engle xii, xiii

Mezey, Naomi xi

Michelman, Frank 483

Mill, J.S. 41, 42, 44, 47-8, 50

Mitchell, William 75-6

Mnookin, Jennifer L. xxiii, 645-701

Montesquieu, Charles de Secondat, Baron de xi

Moore, Sally Falk xii

Moore, Underhill xii

Nader, Laura xii

Negroponte, Nicholas 313, 544

Netanel, Neil W. 70-71, 453, 458, 459, 464, 733

Norgueras, Joan 180, 225

Nussbaum, Martha 207-8

O'Connor, Sandra Day 118

Oldenberg, Ray 594

Ong, Walter 17, 19

Orloff, Ann Shola 49

Orwell, George 134

Overton, Spencer 515

Ozouf, Jacques 34

Packer, Herbert xii

Palfrey, John G. Jr. xvii

Pantaloni, Nazareth A. M. III 18, 21

Park, Jongsun 176, 177, 223-4

Parsons, Talcott xi

Pelassy, Dominique 43

Peltason, Jack xii

Perritt, Henry H. Jr 10

Plato 82

Pocock, J.G.A. 30

Polanyi, K. 152

Pollack, Mark A. xiii

Post, David G. xiv,xvi, 10, 67-8, 118, 119, 733

Pound, Roscoe xi

Press, Arthur E. xii
Prest, Wilfred R. 29

Przeworski, Adam 43

Radin, Margaret Jane xvii, xxi, xxii, 235-49, 482, 483

Ragin, Charles C. 39, 40, 47, 48, 49

Rajagopal, Balakrishnan xiii

Rawls, John 151, 210, 523

Redfield, Robert xi

Reichman, Jerome 136

Reidenberg, Joel R. xv, xvi, 228

Rheingold, Howard 75

Richards, I.A. 80, 84-5

Riles, Annelise xiii

Roberts, Owen J. 109

Robson, Reginald A. xii

Rodriquez-Garavito, Cesar A. xiii

Rose, Arnold M. xii

Rose, Carol 136

Rosenthal, Raymond 15

Ross, Richard J. xix, xx, xxiii, 9-56

Rossiter, Clinton 350

Roy, Arundhati 561-7

Samuelson, Pamela 10, 18, 246, 275

Savigny, Frederick Charles von xi

Schmidhauser, John R. xii

Schubert, Glendon xii

Schwartz, Paul 504

Sciulli, David 150-51

Sen, Amartya 544

Shaffer, Gregory C. xiii

Shapiro, Andrew L. 71-2

Sheppard, William 29

Sikkink, Kathryn xiii

Silbey, Susan S. xii

Simpson, A.W.B. 28, 30

Singer, Joseph 138, 482-3

Skover, David M. 9 passim

Smelser, Neil J. 49

Smith, William 32

Socrates 82

Sommerville, J.P. 30

Stein, Allan R. xiv

Stern, Rachel E. xiii

Sunder, Madhavi 552

Sunstein, Cass R. xvii, 22, 541 passim

Susskind, Richard E. 10

Teubner, Gunther xx, 143-68 
Teune, Henry 43

Thomas, Keith 34

Tönnies, Ferdinand xi

Tufte, Edward R. 5

Turkle, Sherry xix, xx, 3-7, 677-8, 681

Turner, Mark 89, 90, 91

Unger, Roberto xii, 645, 648, 650, 651, 655, 668, $669,671,685,690,693$

Volokh, Eugene 10, 18, 294

von Mehren, Arthur 189, 202-3

Walsham, Alexandra 33

Warner, Michael 35

Warren, Kay B. xiii
Watt, Ian 16

Weber, Max xi, 24, 25, 37, 150

Weinberg, Jonathan 309, 315

Weiser, Philip J. xvii

Westin, Alan 527

Williams, Joan 483

Williams, Patricia 18

Wilson, James 32

Wu, Timothy 71, 72, 110

Young, Iris 208-9, 232

Zaret, David 35

Zeisel, Hans xii

Zimmerman, Diane 516

Zittrain, Jonathan xvii, xviii 